\title{
PENDEKATAN PER SE ILLEGAL DAN RULE OF REASON DALAM HUKUM PERSAINGAN (PERBANDINGAN INDONESIA-MALAYSIA)
}

\author{
Hanif Nur Widhiyanti
}

\author{
Fakultas Hukum Universitas Brawijaya Malang \\ J1. MT. Haryono No. 169 Malang \\ Email: hanifahsigit@gmail.com
}

\begin{abstract}
Approach to the nature of illegal per se and rule of reason prohibition has long been applied in determining whether an act hinder competition or not. Competition law of Indonesia and Malaysia also implement a ban properties per se illegal or rule of reason, but did not mention explicitly in the formulation of laws and regulations. The unfirm arrangement model imposes a difficult responsibility for institution of business competition authorities to be able to precisely define the reference as a measure that should be used in assessing an anti-competitive act. This research is a normative law with legislation approach and comparative law. From the discussion, it was concluded that the application of the nature of illegal per se and rule of reason prohibition in Law No. 5 of 1999 and the Competition Act 2010 of Malaysia implemented through an assessment of how the result level of an anti-competitive actions capable of distorting the market and blocking, thus eliminating competition completely. Consideration was also made based on the alignment between normative rules in the Act with the basic theory of competition itself. Thus, the rule of law in the enforcement of competition law can be maintained.
\end{abstract}

Key words: competition, per se illegal, rule of reasons

\begin{abstract}
Abstrak
Baik pendekatan sifat larangan per se illegal maupun rule of reason telah lama diterapkan dalam menetapkan apakah suatu perbuatan menghambat persaingan ataukah tidak. Hukum Persaingan Indonesia dan Malaysia pun menerapkan sifat larangan per se illegal atau rule of reason namun tidak menyebutkan secara tegas dalam rumusan peraturan perundang-undangannya. Model pengaturan tidak secara tegas tersebut, telah membebankan sebuah tanggung jawab yang tidak mudah bagi lembaga otoritas persaingan usaha untuk mampu secara tepat mulai dari menentukan acuan sebagai ukuran yang harus digunakan dalam menilai sebuah perbuatan anti persaingan. Penelitian ini merupakan penelitian hukum normatif dengan pendekatan perundang-undangan dan pendekatan perbandingan hukum. dari hasil pembahasan disimpulkan, penerapan sifat larangan per se illegal ataukah rule of reason dalam Undang-Undang Nomor 5 Tahun 1999 dan Akta Persaingan 2010 Malaysia ialah selain melalui sebuah penilaian bagaimana tingkatan akibat dari sebuah perbuatan anti persaingan mampu mendistorsi pasar dan menghalangi hingga menghilangkan persaingan sama sekali. Pertimbangan juga di dasarkan kepada keselarasan antara peraturan normatif dalam Undang-Undang dengan teori dasar persaingan itu sendiri. Dengan demikian kepastian hukum dalam penegakan hukum persaingan dapat terus ditegakkan
\end{abstract}

Kata kunci: persaingan, per se illegal dan rule of reason 


\section{Latar Belakang}

Seperti diketahui bersama, bahwa pengaturan hukum persaingan usaha, selain bertujuan untuk melindungi kepentingan pelaku usaha dari penguasaan pasar dan perlaku bisnis yang anti persaingan, sehingga dapat tercipta persaingan usaha yang sehat dan efisien dalam melakukan kegiatan ekonomi, juga bertujuan untuk melindungi kepentingan umum. Kedua tujuan tersebut harus terefleksikan dalam pengaturan undangundang persaingan usaha. Berkenaan dengan hal tersebut, baik melalui pendekatan struktur maupun perilaku, maka pengaturan mengenai persaingan usaha ditetapkan melalui dua sifat pendekatan norma larangan yaitu larangan yang bersifat per se illegal dan larangan yang bersifat rule of reason. Baik pendekatan per se illegal maupun rule of reason telah lama diterapkan dalam menetapkan apakah suatu perbuatan menghambat persaingan ataukah tidak. $^{1}$

Pendekatan per se illegal adalah menyatakan setiap perjanjian atau kegiatan usaha tertentu sebagai ilegal, tanpa pembuktian lebih lanjut atas dampak yang ditimbulkan dari perjanjian atau kegiatan usaha tersebut. Kegiatan yang dianggap sebagai per se illegal biasanya meliputi penetapan harga secara kolusif atas produk tertentu, serta pengaturan harga penjualan kembali. Namun, sebaliknya pendekatan rule of reason adalah suatu pendekatan yang digunakan oleh lembaga otoritas persaingan usaha untuk membuat evaluasi mengenai akibat perjanjian atau kegiatan usaha tertentu, guna menentukan apakah suatu perjanjian atau kegiatan tersebut bersifat menghambat atau mendukung persaingan. $^{2}$

Demikian halnya dengan Undang-Undang Nomor 5 Tahun 1999 tentang Larangan Praktek Monopoli dan Persaingan Usaha Tidak Sehat (selanjutnya disebut dengan UU No. 5 Tahun 1999) pun mengandungi ketentuan-ketentuan dimana pelaku usaha dianggap melakukan pelanggaran terhadap ketentuan-ketentuan tersebut, walaupun tidak tidak secara eksplisit dinyatakan sebuah pasar tertentu mengunakan pendekatan per se illegal atau rule of reason. Hal yang sama pun dianut oleh Malaysia, melalui Akta Persaingan 2010, pengaturan mengenai persaingan usaha di Malaysia, diatur tanpa juga menyebut secara tegas sebuah ketentuan persaingan dinyatakan berdasarkan pendekatan per se illegal atau rule of reason.

Suatu tindakan yang dinyatakan bersifat anti persaingan, serta dalam hal menakar akibat

1 Pada tahun 1914, The Sherman Act 1890 disempurnakan dengan dikeluarkannya Act to Supplement Existing Laws Against Unlawful Restraints and Monopolies yang dikenal dengan sebutan the Clayton Act. Pada tahun yang sama diterbitkan Act to Create a Federal Trade Commission, to Define Its Powers and Duties, and for Other Purposes yang lebih dikenal dengan the Federal Trade Commission Act. Kemudian pada tahun 1936, the Clayton Act disempurnakan dengan the Robinson-Patman Act, di mana penyempurnaannya terbatas pada Pasal 2 the Clayton Act yang mengatur tentang Diskriminasi Harga, dalam Stephen F. Ross, Principles of Antitrust Law, The Foundation Press, Inc., Westbury New York, 1993, hal. 395-399.

2 R. Sheyam Khemani and D. M. Shapiro, Glossary af Industrial Organisation Economics and Competition Law, OECD, Paris, 1996, hlm. 51. 
yang ditimbulkan pada proses persaingan tentunya harus melewati beberapa acuan. Acuan berupa ukuran untuk menakar akibat sebuah perbuatan antipersaingan haruslah bersifat nyata dan substansial. Contoh-nya dalam hal perjanjian penetapan harga, dengan melihat akibat yang ditimbulkan pada persaingan dan dengan melihat tindakan atau hambatan yang dilakukan apakah akan mengakibatkan pelaku dapat menggunakan kekuatan pasarnya untuk menghambat persaingan.

Model pengaturan hukum persaingan yang tidak secara tegas menyatakan konsep pendekatan per se illegal atau rule of reason, telah membebankan sebuah tanggung jawab yang tidak mudah bagi lembaga otoritas persaingan usaha untuk mampu secara tepat mulai dari menentukan acuan sebagai ukuran yang harus digunakan dalam menilai sebuah perbuatan anti persaingan, hingga pada akhirnya membuat sebuah kesimpulan apakah sebuah perbuatan yang bersifat anti persaingan ditetapkan dengan pendekatan per se illegal ataukah rule of reason. Oleh karena itu, untuk dapat menentukan apakah suatu perbuatan atau suatu perjanjian yang dilarang telah melanggar ketentuan persaingan usaha, maka undang-undang menggunakan pendekatan per se illegal dan rule of reason sebagai alat bukti. $^{3}$
Di dalam beberapa kasus persaingan, kedua pendekatan sifat larangan ini tidaklah mudah untuk diterapkan. Lembaga otoritas persaingan harus mempunyai sebuah persepsi yang sama terhadap pengartian yang menyatakan suatu tindakan dinyatakan mutlak melanggar ataupun dapat diputuskan setelah melihat kepada argumentasi alasan rasionalistas sebuah tindakan. Dan berdasarkan pengalaman di negara-negara lain, terutama di Amerika Serikat, penilaian berdasarkan per se illegal dalam kenyataannya dapat berubah menjadi rule of reason atau sebaliknya, untuk mengetahui apakah suatu tindakan pelaku usaha menghambat atau mendorong adanya persaingan. Perbedaan pendekatan pada dasarnya dipengaruhi oleh partimbangan kepatutan, keadilan, efisisensi, kepastian hukum, serta kemanfaatan bagi masyarakat.

Mengenai pengaturan hukum persaingan ini, khususnya di wilayah Asia Tenggara, pada tahun 2007 negara-negara anggota Association of Southeast Asian Nation (ASEAN) telah menyepakati ASEAN Economic Community pada tahun 2015 dengan salah satu karakteristik kuncinya ialah tercapainya Competitive Economic Region melalui pelaksanaan kebijakan dan undang-undang persaingan. ${ }^{4}$ Dengan adanya kesepakatan untuk mewujudkan ASEAN Economic Community, maka nantinya akan

3 Elyta Ras Ginting, Hukum Anti Monopoli Indonesia, Analisis dan Pebandingan UU No. 5 Tahun 1999, Bandung, Citra Aditya Bakti, 2001, hlm. 27.

4 Ahmad Junaidi, Asas Comity dan Hukum Persaingan di ASEAN, Media Berkala Komisi Pengawas Persaingan Usaha, Edisi 42, 2013, hlm. 20. 
terbentuk pasar bersama dimana transaksi perdagangan yang sebelumnya terpisah di sepuluh negaraanggota yaitu Malaysia, Indonesia, Singapore, Brunei, Filipina, Thailand, Vietnam, Kamboja, Laos dan Myanmar akan menyatu dan berintegrasi dalam satu pasar bersama-sama.

Hal ini membawa konsekswensi jika ada pelaku usaha di Indonesia berkeinginan untuk melakukan ekspansi usaha di lingkup ASEAN atau berhubungan dengan pelaku usaha di negara-negara anggota ASEAN lainnya, maka pelaku usaha tersebut harus memahami hukum Negara setempat termasuk undang-undang persaingan. Oleh karena itu persamaan pandangan mengenai undangundang persaingan di antara negara-negara anggota ASEAN sangat diperlukan, termasuk mengenai konsep pendekatan larangan terhadap perbuatan anti persaingan.

Penelitian ini akan melakukan study perbandingan hukum persaingan di Indonesia dan di Malaysia. Pemilihan kedua negara ini dipilih selain dikarenakan kedua-duanya adalah Negara anggota ASEAN, juga dikarenakan lokasi kedua Negara yang saling berdekatan, sehingga kemungkinan adanya interaksi perdagangan diantara kedua-nya pun sangat tinggi. Berdasarkan data Badan Pusat Statistik (BPS), tren perdagangan Indonesia-Malaysia juga menunjukkan peningkatan dari tahun ke tahun. Transaksi ekspor kedua negara juga naik-turun. Dalam beberapa tahun Malaysia mengalami surplus perdagangan, sebaliknya dalam tahun-tahun lainnya Indonesia yang beruntung. Pada paruh pertama 2010, ekspor non migas Indonesia mencatat surplus sekitar US\$973 juta. Nilai ekspor nonmigas Indonesia ke Malaysia selama semester I-2010 mencapai US\$3,15 miliar, sedangkan impor tercatat US\$2,18 miliar. $^{5}$

Pada tahun 2012 yang lalu Malaysia telah mempunyai peraturan mengenai persaingan usaha yang diatur dalam Akta Persaingan 2010. Baik Undang-Undang Nomor 5 Tahun 1999 dan juga Akta Persaingan Malaysia 2010, sama-sama tidak mengatur atau menyebutkan secara tegas sebuah perbuatan anti persaingan ditafsirkan dengan menggunakan pendekatan larangan tertentu, menggunakan pendekatan per se illegal ataukah pendekatan rule of reason. Maka berdasarkan pertimbangan itulah, penelitian ini mencoba menganalisa penerapan pendekatan sifat larangan per se illegal dan rule of reason dalam Undangundang Nomor 5 Tahun 1999 dan dalam Akta Persaingan 2010 Malaysia.

Penelitian ini merupakan penelitian hukum normatif (normative legal research), dengan pendekatan perundang-undangan (statuta approach), dan pendekatan perbandingan hukum (comparative legal study). Menggunakan sumber dari bahan hukum primer, yaitu Undang-Undang Nomor 5 Tahun 1999 dengan Akta Persaingan 2010

5 Viva News, Dagang Indonesia-Malaysia, Siapa Untung?, http://bisnis.news.viva.co.id/news/read/174056dagang-indonesia-malaysia--siapa-untung-, diakses 8 September 2014 pukul 19.15 WIB. 
Malaysia dan putusan-putusan daripada Komisi Pengawas Persaingan Usaha (KPPU) dan Malaysia Competition Committe (MyCC), bahan hukum sekunder dan bahan hukum tertier. Bahan-bahan hukum tersebut diperoleh melalui studi kepustakaan dan studi dokumentasi. Keseluruhan bahan hukum yang telah dikumpulkan melalui studi kepustakaan dan studi dokumentasi, dianalisa menggunakan interpretasi gramatikal dan akan dianalisa lebih lanjut menggunakan teknik analisa yuridis kualitatif.

\section{Pembahasan}

\section{A. Perbedaan Sifat Larangan Per Se Illegal dengan Rule of Reason}

Larangan per se illegal, membayangkan bahwa beberapa jenis perjanjian usaha, seperti penetapan harga, dianggap secara nyata bersifat anti-kompetitif dan merugikan kepentingan umum, tanpa sebuah urgensi untuk menentukan apakah perjanjian itu sebenarnya telah menciderai persaingan di dalam pasar ataukah tidak. ${ }^{6}$ Sebuah perbuatan yang menggunakan pendekatan larangan per se illegal artinya perbuatan tersebut dianggap sebagai perbuatan antipersaingan dan perbuatan tersebut dilarang, terlepas dari apakah perbuatan itu memiliki tujuan, apakah perbuatan itu mempunyai dampak yang mungkin secara substansial mengurangi atau menghalangi persaingan. Alasan dibalik konsep larangan per se illegal ialah bahwa sebuah perbuatan dilarang untuk dilakukan karena sangat mungkin merugikan bagi kesejahteraan ekonomi, sehingga tidak mungkin bermanfaat, yang harus dilarang tanpa pertanyaan lebih lanjut tentang dampaknya terhadap persaingan.

Selanjutnya sifat larangan rule of reason adalah suatu pendekatan yang digunakan oleh lembaga otoritas persaingan usaha untuk membuat evaluasi mengenai dampak dari sebuah perjanjian atau kegiatan usaha tertentu, guna menentukan apakah suatu perjanjian atau kegiatan tersebut bersifat menghalangi atau justru bersifatmendukung persaingan. ${ }^{7}$ Sebuah

6 "Per se violations in anti-trust law, term that implies that certain types of business agreements, such as price fixing, are considered inherently anti-competitive and injurious to the public without any need to determine if the agreement has actually injured market competition Bryan A. Graner, Black's Law Dictionary, Eighth Edition, 2004, hal 1332.

7 "The Rule of reason is a legal approach by competition authorities or the courts where an attempt is made to evaluate the pro-competitive features of a restrictive business practice against its anticompetitive effects in order to decide whether or not the practice should be prohibited. Some market restrictions which prima facie give rise to competition issues may on further examination be found to have valid efficiency-enhancing benefits. For example, a manufacturer may restrict supply of a product in different geographic markets only to existing retailers so that they earn higher profits and have an incentive to advertise the product and provide better service to customers. This may have the effect of expanding the demand for the manufacturer's product more than the increase in quantity demanded at a lower price. The opposite of the rule of reason approach is to declare certain business practices per se illegal, that is, always illegal are per se illegal. Dalam Glossary of Industrial Organisation Economics and Competition Law, compiled by R. S. Khemani and D. M. Shapiro, commissioned by the Directorate for Financial, Fiscal and Enterprise Affairs, OECD, 1993. OECD, Glossary of Statistical Terms, http://stats.oecd.org/glossary/detail.asp?ID=3305, diakses 1 Agustus 2011 pukul 20.00 WIB. 
perbuatan akan menggunakan larangan rule of reason, maka harus dimulai dengan pencarian daripada fakta-fakta dan kemudian menguji apakah perbuatan tersebut menunjukkan adanya akibat yang bersifat anti persaingan atau adanya kerugian yang nyata terhadap persaingan dan bukan kepada pembuktian terhadap apakah perbuatan-perbuatan tersebut bersifat adil ataupun menyakitkan. ${ }^{8}$

Sebagaimana dijelaskan, bahwa penerapan kedua pendekatan sifat larangan tersebut tidaklah mudah. Lembaga otoritas persaingan harus mempunyai sebuah persepsi yang sama terhadap pengertian yang menyatakan suatu tindakan dinyatakan mutlak melanggar ataupun dapat diputuskan setelah melihat kepada argumentasi alasan rasionalistas sebuah tindakan. Setiap negara mempunyai kewenangan untuk menentukan dasar penilaian apakah sebuah perbuatan anti persaingan ditetapkan berdasarkan larangan per se illegal atau rule of reason. Dan sebagai konsekwensinya ialah terdapat perbedaan dasar pertimbangan untuk menentukan sebuah perbuatan anti persaingan diatur secara pendekatan larangan per se illegal atau rule of reason.
B. Penggunaan Sifat Larangan Per Se Illegal dan Rule of Reason dalam Undang-Undang Nomor 5 Tahun 1999

Kedua metode pendekatan tersebut juga digunakan dalam Undang-Undang Nomor 5 Tahun 1999. Namun demikian Undang-Undang Nomor 5 Tahun 1999, tidak menyatakan secara eksplisit mana saja perbuatan yang diletakkan dibawah larangan per se dan mana saja perbuatan yang bersifat rule of reason. Terdapat sebuah petunjuk dalam rumusan ketentuan Undang-Undang Nomor 5 Tahun 1999, untuk menentukan sifat larangan yang akan diterapkan. Jikalau didalam pasal mengandung kalimat "dapat mengakibatkan terjadinya praktek monopoli dan/atau persaingan usaha tidak sehat" maka perbuatan anti persaingan di dalam pasal tersebut bersifat rule of reason. Dan sebaliknya jikalau tidak mengandung frasa mengenai kemungkinan akibat, maka perbuatan anti dalam ketentuan pasal tersebut bersifat per se illegal. Dengan kondisi yang demikian, maka Undang-Undang Nomor 5 Tahun 1999, menyerahkan penentuan pendekatan larangan keatas perbuatan anti persaingan menggunakan per se atau rule of reason

8 Under 'rule of reason' test for determining whether alleged acts violated $\S 1$ the Sherman Anti-Trust act (15 U.S.C.A. §1), which declares conspiracies in restraint of trade to be illegal, fact finder must weigh all circumstances of the case to decide whether practice unreasonably restraints competition, and the test requires that plaintiff show anticompetitive effects, or actual harm to competition, and not whether the practices were unfair or tortuous. Bryan A. Graner, Black's Law Dictionary, Eighth Edition, 2004, hlm. 1332. 
kepada KPPU. Hal ini termuat jelas dalam ketentuan Pasal 35 mengenai tugas komisi. ${ }^{9}$

Dengan berpedoman dengan ada tidaknya frasa yang mensyaratkan bahwa perbuatan anti persaingan baru akan dianggap melawan Undang-Undang jika telah menimbulkan akibat terhadap persaingan yang sehat atau menimbulkan praktek monopoli, maka secara keseluruhan terdapat tiga jenis penggolongan sifat perbuatan anti persaingan di dalam Undang-Undang Nomor 5 Tahun 1999 terbagi dalam 3 jenis, yaitu bersifat per se; bersifat rule of reason; dan secara normatif bersifat per se, namun dalam Putusan KPPU menerapkan secara rule of reason. Berikut ini gambaran secara keseluruhan sifat larangan dalam masing-masing jenis perbuatan anti persaingan:

Tabel 1. Klasifikasi Larangan dalam Perbuatan Anti Persaingan dalam Undangundang Nomor 5 Tahun 1999

\begin{tabular}{|c|c|c|c|}
\hline No. & Jenis Perjanjian & Pasal & Sifat Larangan \\
\hline 1. & Oligopoli & 4 & Rule of reason \\
\hline 2. & Penetapan harga & 5 & Per se ilegal \\
\hline 3. & Diskriminasi harga & 6 & Per se ilegal \\
\hline 4. & Perjanjian penetapan harga predator & 7 & Rule of reason \\
\hline 5. & Penetapan harga jualan semula & 8 & Rule of reason \\
\hline 6. & Perjanjian pembagian wilayah & 9 & Rule of reason \\
\hline 7. & Pemboikotan & 10 & Per se ilegal \\
\hline 8. & Kartel & 11 & Rule of reason \\
\hline 9. & Trust & 12 & Rule of reason \\
\hline 10. & Oligopsoni & 13 & Rule of reason \\
\hline 11. & Integrasi vartikal & 14 & Rule of reason \\
\hline 12. & Exclusive Distribution Agreement & $15(1)$ & Per se ilegal \\
\hline 13. & Tying agreement pasal & $15(2)$ & Per se ilegal \\
\hline 14. & Vartical Agreement on Discount pasal & $15(3)$ & Per se ilegal \\
\hline 15. & Perjanjian luar negeri & 16 & Rule of reason \\
\hline 16. & Monopoli & 17 & Rule of reason \\
\hline 17. & Monopsoni & 18 & Rule of reason \\
\hline 18. & Penguasaan pasar & 19 & Rule of reason \\
\hline 19. & Kegiatan Menjual Rugi & 20 & Rule of reason \\
\hline 20. & Kecurangan Dalam Menetapkan Biaya Produksi & 21 & Rule of reason \\
\hline 21. & Persekongkolan tender & 22 & Rule of reason \\
\hline 22. & $\begin{array}{l}\text { Persekongkolan Membocorkan Rahasia Dagang/Peru- } \\
\text { sahaan }\end{array}$ & 23 & Rule of reason \\
\hline 23. & Persekongkolan Menghambat Perdagangan & 24 & Per se ilegal \\
\hline 24. & Posisi dominan & 25 & $\begin{array}{c}\text { Normatif Per se ilegal } \\
\text { Putusan KPPU : Rule of reason }\end{array}$ \\
\hline 25. & Jabatan rangkap & 26 & Rule of reason \\
\hline 26. & Pemilikan saham & 27 & $\begin{array}{c}\text { Normatif Per se ilegal } \\
\text { Putusan KPPU: Rule of reason }\end{array}$ \\
\hline 27. & Merger, akuisisi dan konsolidasi & $28-29$ & Rule of reason \\
\hline
\end{tabular}

\section{Sumber: Undang-undang Nomor 5 Tahun 1999}

9 Pasal 35 Undang-undang Nomor 5 Tahun 1999:

a. melakukan penilaian terhadap perjanjian yang dapat mengakibatkan terjadinya praktek monopoli dan atau persaingan usaha tidak sehat sebagaimana diatur dalam Pasal 4 sampai dengan Pasal 16;

b. melakukan penilaian terhadap kegiatan usaha dan atau tindakan pelaku usaha yang dapat mengakibatkan terjadinya praktek monopoli dan atau persaingan usaha tidak sehat sebagaimana diatur dalam Pasal 17 sampai dengan Pasal 24;

c. melakukan penilaian terhadap ada atau tidaknya penyalahgunaan posisi dominan yang dapat mengakibatkan terjadinya praktek monopoli dan atau persaingan usaha tidak sehat sebagaimana diatur dalam Pasal 25 sampai dengan Pasal 28. 
1. Jenis akibat yang ditimbulkan oleh perbuatan anti persaingan menurut Undang-undang Nomor 5 Tahun 1999

Selanjutnya sebuah perbuatan anti persaingan digolongkan sebagai sebagai suatu kesalahan dibawah Undang-Undang, apabila perbuatan-perbuatan tersebut yang bisa mendatangkan akibat perbuatan praktek monopoli dan/atau telah menghalangi persainganyangsehat.Undang-Undang Nomor 5 Tahun 1999, membedakan antara pengertian "monopoli" dengan "praktik monopoli". Monopoli di artikan sebagai, "penguasaan atas produksi dan atau pemasaran barang dan atau atas konsep jasa tertentu oleh satu pelaku usaha atau satu kelompok pelaku usaha."10 Dan praktek monopoli adalah "pemusatan kekuatan ekonomi oleh satu atau lebih pelaku usaha yang mengakibatkan dikuasainya produksi dan atau pemasaran atas barang dan atau jasa tertentu sehingga menimbulkan persaingan usaha tidak sehat dan dapat merugikan kepentingan umum."

Menurut Ancillary Restraint Doctrine, ${ }^{11}$ bahwa tidak semua monopoli atau pembatasan terhadap persaingan dapat dianggap melawan undang-undang. Hanya perbuatan-perbuatan yang mempengaruhi persaingan secara langsung dan segera, yang dikira sebagai perbuatan melawan undangundang. Apabila kemudian timbul akibat terhadap persaingan dalam pasar yang terjadi secara tidak langsung atau hanya merupakan akibat tambahan semata-mata, maka tindakan tersebut meskipun mempunyai akibat negatif terhadap persaingan, tetap dianggap sebagai tidak melawan undang-undang persaingan.

Sebaliknya, jika akibat negatif terhadap persaingan merupakan sebuah akibat langsung, maka meskipun tindakan tersebut diklasifikasikan sebagai tindakan yang munasabah tetap dianggap sebagai melawan undang-undang persaingan. ${ }^{12}$ Sehingga dalam konteks perundangan, tidak semua bentuk perbuatan monopoli ialah dilarang oleh undang-undang, hanya perbuatan monopoli yang mempunyai akibat terhadap persaingan-lah yang dilarang, dan menurut Undang-Undang Nomor 5 Tahun 1999 itulah yang disebut sebagai "praktik monopoli", yaitu keadaan apabila pelaku usaha melakukan perbuatan anti persaingan dan menimbulkan akibat terhadap kepentingan umum.

Di dalam pasar monopoli dapat menimbulkan pemusatan ekonomi pada satu atau satu kelompok pelaku usaha, dimana diantara mereka tidak terjadi persaingan dan

10 Lihat Pasal 1 angka 1 Akta Persaingan 2010.

11 Hovenkam, indicates that "once a restraint is found to be ancillary, the court pursues its inquiry with a presumption of lawfulness and requires ... proof of power and effects," and he suggests that an ancillary restraint is unlawful if it has "output-reducing tendencies (anticompetitive effects) that are not offset by reasonable justifications or defence. Herbert Hovenkamp, Antiturst, St. Paul Minnesota, West Publishing, 1993, hlm. 326.

12 A.M. Tri Anggraini, Larangan Praktek Monopoli dan Persaingan Usaha Tidak Sehat, Perpustakaan Nasional, Jakarta, 2003, hlm. 211. 
keadaan yang semacam ini akan merugikan kepentingan konsumen. Undang-Undang Nomor 5 Tahun 1999 memberikan definisi pemusatan ekonomi sebagai "Pemusatan kekuatan ekonomi adalah penguasaan yang nyata atas suatu pasar bersangkutan oleh satu atau lebih pelaku usaha sehingga dapat menentukan harga barang dan atau jasa."13 Dengan demikian penunjuk yang dapat digunakan untuk menentukan telah terjadi suatu peristiwa kepekatan kuasa ekonomi adalah apabila telah terjadi "penguasaan atau suatu pasar secara nyata", sehingga barang atau jasa yang diperniagakan kepada konsumen tidak lagi didasarkan pada mekanisma pasar, tetapi ditentukan sendiri oleh seorang pelaku usaha yang telah menguasai pasar berkenaan. ${ }^{14}$

Sementara yang dimaksud sebagai persaingan usaha tidak sehat ialah "Persaingan usaha tidak sehat adalah persaingan antar pelaku usaha dalam menjalankan kegiatan produksi dan atau pemasaran barang dan atau jasa yang dilakukan dengan cara tidak jujur atau melawan hukum atau menghambat persaingan usaha. ${ }^{15}$ Bahwa telah terjadi persaingan yang tidak sehat apabila antar pelaku usaha dalam melakukan kegiatan hasil produksi atau pemasaran barang ecara tidak jujur, melawan undang-undang atau menghambat persaingan.
Praktik monopoli dan persaingan usaha tidak sehat ini dapat menimbulkan adanya pemusatan kekuatan ekonomi pada pelaku usaha tertentu serta dapat menciptakan iklim usaha yang tidak sehat, tidak efektif dan tidak efisien. Akibatnya pertumbuhan dan bekerjanya ekonomi pasar menjadi tidak wajar dan tidak sehat, serta dapat merugikan masyarakat. Berikut ini pembagian jenis akibat yang ditimbulkan oleh perbuatan anti persaingan:

\section{Perbedaan sifat larangan sebuah perbuatan anti persaingan secara normatif dan penerapannya dalam putusan KPPU}

Dari sekian pasal yang mengatur larangan terhadap perbuatan anti persaingan, terdapat dua pasal yang tidak mengandung frasa akibat, artinya secara normatif seharusnya menggunakan larangan per se illegal, namun dalam putusannya KPPU menerapkan justur mengaplikasikan dengan menggunakan larangan rule of reason, artinya sebuah perbuatan anti persaingan baru dianggap melanggar undang-undang ketika terdapat bukti bahwa perbuatan tersebut menimbulkan dampak negatif terhadap persaingan. Hal ini terjadi dalam penerapan pasal 25 mengenai posisi dominan dan pasal 27 mengenai kepemilikan silang.

\footnotetext{
13 Lihat Pasal 1 angka 3 Undang-undang Nomor 5 Tahun 1999.

14 Pasal 1 angka 10 "Pasaran bersangkutan adalah pasaran yang berkaitan dengan jangkauan atau daerah pemasaran tertentu oleh pelaku usaha atas barang dan atau jasa yang sama atau sejenis atau substitusi dari barang dan atau jasa tersebut."

15 Lihat Pasal 1 angka 6 Undang-undang Nomor 5 Tahun 1999.
} 
Tabel 2. Pembagian Jenis Akibat yang Ditimbulkan oleh Perbuatan Anti Persaingan

\begin{tabular}{|c|c|c|c|c|c|}
\hline \multirow[b]{2}{*}{ No. } & \multirow[b]{2}{*}{ Perbuatan anti persaingan } & \multirow[b]{2}{*}{ Pasal } & \multicolumn{3}{|c|}{ Akibat terhadap persaingan } \\
\hline & & & $\begin{array}{l}\text { Praktek } \\
\text { monopoli }\end{array}$ & $\begin{array}{l}\text { Persaingan } \\
\text { Usaha } \\
\text { tidak sehat }\end{array}$ & $\begin{array}{l}\text { Akibat } \\
\text { lainnya }\end{array}$ \\
\hline 1. & Oligopoli & 4 & & & - \\
\hline 2. & Perjanjian penetapan harga predator & 7 & - & & - \\
\hline 3. & Penetapan harga jualan semula & 8 & - & & - \\
\hline 4. & Perjanjian pembagian wilayah & 9 & & & - \\
\hline 5. & Kartel & 11 & & & - \\
\hline 6. & Trust & 12 & & & - \\
\hline 7. & Oligopsoni & 13 & & & - \\
\hline 8. & Integrasi vartikal & 14 & - & & $\begin{array}{l}\text { Merugikan } \\
\text { masyarakat }\end{array}$ \\
\hline 9. & Perjanjian luar negeri & 16 & - & & - \\
\hline 10. & Monopoli & 17 & - & & - \\
\hline 11. & Monopsoni & 18 & & & - \\
\hline 12. & Penguasaan pasar & 19 & & & - \\
\hline 13. & Kegiatan Menjual Rugi & 20 & & & - \\
\hline 14. & $\begin{array}{l}\text { Kecurangan Dalam Menetapkan Biaya } \\
\text { Produksi }\end{array}$ & 21 & - & & - \\
\hline 15. & Persekongkolan tender & 22 & - & & - \\
\hline 16. & $\begin{array}{l}\text { Persekongkolan Membocorkan Rahasia } \\
\text { Dagang/Perusahaan }\end{array}$ & 23 & - & & - \\
\hline 17. & $\begin{array}{l}\text { Dengan memperhatikan lingkup pekerjaan } \\
\text { akuntan tersebut membawa konsekuensi } \\
\text { perubahan bagi tugas akuntan yaitu: }\end{array}$ & 24 & & - & - \\
\hline 18. & Posisi dominan & 25 & - & - & - \\
\hline 19. & Jabatan rangkap & 26 & & & - \\
\hline 20. & Pemilikan saham & 27 & - & - & - \\
\hline
\end{tabular}

Sumber: Data primer, diolah, 2014

a. Penyalahgunaan posisi dominan posisi yang ditempati oleh perusahaan yang sebagai perbuatan anti persaingan

Posisi dominan ialah keadaan ketika pelaku usaha unggul di pasar bersangkutan dan hal ini menjadi salah satu tujuan pelaku usaha untuk memenangkan persaingan. Oleh karena itu, adalah sebuah kewajaran apabila pelaku usaha berusaha menjadi lebih unggul pada pasar yang bersangkutan. Pada prespektktif ekonomi, posisi dominan adalah memiliki pangsa pasar terbesar. Dengan pangsa pasar yang besar tersebut perusahaan mempunyai market power. Dengan market power tersebut, perusahaan yang dominan tersebut dapat melakukan tindakan atau strategi tanpa dipengaruhi oleh perusahaan pesaingnya. ${ }^{16}$

Sehingga dengan demikian pada prinsipnya setiap pelaku usaha mempunyai

16 Andi Fahmi Lubis, et.al, Persaingan Usaha antara Teks dan Konteks, Published and Printed with Support of Deutsche Gesellschaft für Technische Zusammenarbeit (GTZ) GmbH, Jakarta 2009, hlm. 166. 
kemungkinan untuk menguasai pasar secara dominan, dimana drinya dianggap menduduki posisi dominan atas pelaku usaha atau kelompok pelaku usaha pesaingnya dalam menguasai pangsa pasar atau suatu posisi yang menempatkan pelaku usah lebih tinggi atau paling tinggi diantara pelaku usaha atau sekelompok pelaku usaha pesaingnya dalam kaitannya dengan penguasaan pangsa pasarnya, kemampuan keuangan, kemampuan akses pada pasokan atau penjualan serta kemampuan untuk menyesuaikan pasokan atau permintaan barang atau jasa tertentu. ${ }^{17}$

Posisi dominan dalam Undang-Undang Nomor 5 Tahun 1999, di artikan sebagai berikut:

Posisi dominan adalah keadaan di mana pelaku usaha tidak mempunyai pesaing yang berarti di pasar bersangkutan dalam kaitan dengan pangsa pasar yang dikuasai, atau pelaku usaha mempunyai posisi tertinggi di antara pesaingnya di pasar bersangkutan dalam kaitan dengan kemampuan keuangan, kemampuan akses pada pasokan atau penjualan, serta kemampuan untuk menyesuaikan pasokan atau permintaan barang atau jasa tertentu.
Berdasarkan rumusan diatas, bahwa seorang pelaku usaha dianggap mempunyai posisi tertinggi diantara pesaingnya ialah ketika pelaku usaha tersebut menguasai pangsa pasar, mempunyai kemampuan keuangan, mempunyai kemampuan akses pada pasokan atau penjualan dan kemampuan menyesuaikan pasokan atau permintaan barang atau jasa tertentu. Oleh karena itu menurut hukum hanya seorang pesaing yang mempunyai posisi dominan-lah yang dapat menguasai posisi dominan di pasar bersangkutan. ${ }^{18}$

Pada dasarnya posisi dominan dalam hukum persaingan usaha tidaklah dilarang, sepanjang proses yang untuk mencapai posisi dominan tersebut dilakukan tidak dengan caracara yang bersifat anti persaingan, melainkan melalui cara yang fair, dengan melakukan innovasi, perbaikan kualitas dan effisiensi biaya produksi. Atau dengan kata lain, yang dilarang oleh hukum persaingan ialah ketika pelaku usaha yang mempunyai posisi dominan tersebut menyalahgunaan posisi dominan yang ia miliki untuk memenangkan persaingan.

17 Dalam hukum yang berlaku untuk Masyarakat Eropa, yaitu hukum yang bersumber dari Traktat Roma 1957, maka penyalahgunaan posisi dominan dapat terjadi seoerti dalam contoh sebagai berikut

1. Pemaksaan harga pembelian atau penjualan yang tidak wajar atau keberadaan perdagangan yang tidak waja, langsung atau tidak langsung;

2. Pembatasan produksi, pasar, atau perkembangan teknis terhadap prasangka konsumen;

3. Penerapan kondisi yang tidak sama untuk transaksi yang saa dalam perdagangan dengan pihak lain, sehingga menempatkannya pada persaingan yang tidak menguntungkan;

4. Kesimpulan sendiri mengenai subyek kontrak untuk mendapatkan persetujuan dari pihak lain tenang kewajiban tambahan yang karena sifatnya atau menurut pemakaian komersialnya, tidak mempunyai hubungan dengan subyek kontrak seperti itu.

Dalam Rachmadi Usman, Hukum Persaingan Usaha di Indonesia dalam Teori dan Praktik serta

Penerapannya di Indonesia, Sinar Grafika, Jakarta, 2012, hlm. 84.

18 Andi Fahmi Lubis, et.al, Op.cit., hlm. 167. 
Memiliki posisi dominan di pasar membuka peluang kepada pihak yang memiliki posisi dominan tersebut dapat dengan mudah mendikte pasar dan menetapkan syarat-syarat yang tidak sesuai dengan kehendak pasar. Oleh karena itu posisi dominan di pasar memanglah sangat rentan untuk disalahgunakan. ${ }^{19}$ Dengan adanya penguasaan pasar, maka akan terbuka kesempatan bagi pelaku usaha melakukan praktik monopoli, yaitu apabila pelaku usaha menggunakan kekuatan pasar atau posisi dominannya untuk itu, yang ebrarti terdapat penyalahgunaan terhadap posisi dominan yang dimilikinya. ${ }^{20}$

Maka seirama dengan beberapa penjelasan di atas, peraturan posisi dominan dalam pasal 25, juga diarahkan kepada larangan penyalahgunaan posisi dominan. Dan seorang pelaku usaha atau sekelompok pelaku usaha dianggap memiliki posisi dominan maka ia dapat melakukan beberapa bentuk penyalahgunaan posisi dominan sebagai berikut :

1. menetapkan syarat-syarat perdagangan dengan tujuan untuk mencegah dan atau menghalangi konsumen memperoleh barang dan atau jasa yang bersaing, baik dari segi harga maupun kualitas; atau

2. membatasi pasar dan pengembangan teknologi; atau menghambat pelaku usaha lain yang berpotensi menjadi pesaing untuk memasuki pasar bersangkutan.
Sehingga jelas bahwa penyalahgunaan posisi dominan seperti diatas dapat mengakibatkan terjadinya praktek monopoli dan/atau persaingan usaha tidak sehat. Kemudian Undang-Undang Nomor 5 Tahun 1999 menyebutkan lebih lanjut, seorang pelaku usaha memiliki posisi dominan sebagaimana dimaksud ayat (1) apabila, memenuhi syarat sebagai berikut:

a. satu pelaku usaha atau satu kelompok pelaku usaha menguasai 50\% (lima puluh persen) atau lebih pangsa pasar satu jenis barang atau jasa tertentu; atau

b. dua atau tiga pelaku usaha atau kelompok pelaku usaha menguasai 75\% (tujuh puluh lima persen) atau lebih pangsa pasar satu jenis barang atau jasa tertentu.

Pertanyaannya sekarang apakah ketentuan pengusaan pasar seperti disebutkan diatas bersifat absolut ataukah tidak ?. artinya, apabila suatu pelaku usaha sudah menguasai pasar sebesar 50\% (untuk satu pelaku usaha) atau menguasai $75 \%$ untuk satu kelompok pelaku usaha, maka penguasaan pangsa pasar tersebut langsung dilarang ?, jika iya maka pasal 25 ialah bersifat per se illegal, sebab secara ekonomis pengusaan diatas ialah secara signifikan akan menghambat pelaku usaha berkembang berdasarkan persianan usaha yang sehat dan pada akhirnya akan mengganggu jalannya persaingan di pasar bersangkutan.

19 Munir Fuady, Hukum Anti Monopoli Menyongsong Era Persaingan Sehat, Citra Aditya Bakti, Jakarta, 1999, hlm. 87.

20 L. Budi Kagramanto, Larangan Persekongkolan Tender (Prespektif Hukum Persaingan Usaha), Srikandi, 2008, hlm. 211. 


\section{b. Penerapan ketentuan Pasal 25 tentang posisi dominan oleh KPPU}

Dalam praktiknya ketentuan Pasal 25 ini diterapkan secara rule of reason oleh KPPU, hal ini terlihat dalam Putusan KPPU Nomor 09/KPPU-L/2009 berkaitan dengan dugaan praktek monopoli dan/atau persaingan usaha tidak sehat atas akuisisi PT Alfa Retailindo.

Dalam perkara tersebut, KPPU menemukan bukti juga melakukan analisa terhadap dampak syarat perdagangan (trading terms) yang dilakukan oleh PT. Carrefour sebagai berikut:

- bahwa trading terms merupakan perilaku bisnis antara peritel dan pemasok, namun terdapat kecenderungan bahwa trading terms yang selama ini diberlakukan tidak hanya berhubungan langsung dengan penjualan produk dari pemasok, dan cenderung naik dari tahun ke tahun tanpa justifikasi yang jelas;

- terdapat syarat additional conditional rebate pada trading terms yang tidak sesuai dengan peraturan perundang-undangan yang ada sehingga menunjukkan trading terms PT. Carrefour melanggar hukum dan peraturan perundangan yang berlaku

- trading terms yang dilakukan pesaing dari PT. Carrefour yang cenderung meniru trading terms PT. Carrefour, sehingga besaran trading terms yang diterima pemasok pada pasar pesaing juga ikut naik dan menghalangi pemasok untuk mendapatkan pilihan trading terms yang bersaing;
- Dampak dari perilaku ini menyebabkan pemasok tidak mendapatkan ruang yang fleksibel dalam mendapatkan trading terms yang lebih kecil. Akibatnya insentif bagi pemasok dalam melakukan inovasi produk-produk baru akan berkurang karena keuntungan yang seharusnya bisa dinikmatinya akan diserap habis oleh PT. Carrefour dan peritel modern;

- PT. Carrefour menggunakan posisi tawarnya untuk menekan pemasok yang berdampak pada lessening competition di pasar bersangkutan.

- Majelis Komisi menyimpulkan bahwa dampaksyaratperdagangan(tradingterms) yang diterapkan oleh Terlapor terhadap pemasok menimbulkan persaingan yang tidak sehat dan menghambat konsumen memperoleh barang dan jasa yang bersaing.

Dari kasus "trading terms: tersebut diatas bahwa titik kesalahan PT Carrefour ialah adanya penyalahgunaan posisi dominan yang dianggap menimbulkan persaingan usaha yang tidak sehat, oleh karena itu posisi dominan dalam pasal 25 diklasifikasikan sebagai rule of reason.

\section{c. Penerapan Pasal 27 tentang kepemilikan oleh KPPU}

Hal yang sama terjadi dalam aplikasi pasal 27 mengenai larangan pemilikan saham mayoritas pada beberapa perusahaan sejenis yang melakukan kegiatan usaha dalam bidang yang sama pada pasar yang bersangkutan yang sama, atau mendirikan beberapa perusahaan 
yang memiliki kegiatan usaha yang sama pada pasar bersangkutan yang apabila mengakibatkan:

a. satu pelaku usaha atau satu kelompok pelaku usaha menguasai lebih dari 50\% (lima puluh persen) pangsa pasar satu jenis barang atau jasa tertentu;

b. dua atau tiga pelaku usaha atau kelompok pelaku usaha menguasai lebih dari $75 \%$ (tujuh puluh lima persen) pangsa pasar satu jenis barang atau jasa tertentu.

Hubungan afiliasi pelaku usaha yang satu dengan yang lain dapat dilihat dari aspek kepemilikan saham suatu pelaku usaha di dua atau lebih pelaku usaha yang bergerak dibidang usaha yang sama atau dengan pelaku usaha yang lain. Ketika seorang pelaku usaha diduga melakukan pelanggaran terhadap Undang-Undang Nomor 5 Tahun 1999, maka pertanyaannya ialah apakah pelaku usaha tersebut mempunyai posisi dominan?. Jika iya, bagaimana pelaku usaha tersebut melakukan penyalahgunaan posisi dominannya, maka yang akan dilakukan adalah tinggal membuktikan, apakah pelaku usaha tersebut benar-benar melakukan penyalahgunaan posisi dominannya dan bagaimana pelaku usaha tersebut melakukan penyalahgunaan posisi dominannya.

Namun jika jawabannya adalah pelaku usaha tidak mempunyai posisi dominan, bagaimana terlapor dapat melakukan persaingan usaha tidak sehat di pasar yang bersangkutan? Dan hal yang perlu dicari tahu dan dibuktikan adalah apakah pasar yang bersangkutan terdistorsi atau tidak. Bentuk pasar terdistorsi misalnya pelaku usaha lain tidak dapat masuk ke pasar yang bersangkutan, karena adanya hambatanhambatan pasar (entry barrier) atau apakah terlapor mempunyai hubungan terafiliasi dengan pelaku usaha lain sehingga dapat melakukan hambatan-hambatan persaingan usaha? Pertanyaan-pertanyaan tersebut diatas adalah sebuah elaborasi penting dalam proses pemahaman tentang apa yang dimaksuddengan posisi dominan dan penyalahgunaannya, termasuk pula peruntukan pasal 27 mengenai kepemilikan silang.

Mengenai perspektif terhadap Pasal 27, dalam kasus Temasek, KPPU juga menggunakan perspektif maksimalis tidak hanya melakukan analisa terhadap unsur pelanggaran Pasal 27 yaitu, adanya pelaku usaha; memiliki saham di beberapa perusahaan; menguasai pasar; dan perilaku penyalahgunaan posisi dominan, namun juga melakukan analisa dampak negatif terhadap persaingan. Ini menunjukkan bahawa pemilikan saham mayoritas pada perusahaan sejenis sebagai salah satu bentuk penyalahgunaan kedudukan dominan, iaah dilarang jika menimbulkan akibat negatif terhadap persaingan. Itu artinya pula bersifat rule of reason dan bukan per se illegal.

Dalam Putusan Temasek, Putusan Perkara Nomor 07/KPPU-L/2007, KPPU melakukan analisa terhadap dampak dari Cross-ownership yang dilakukan Kelompok Temasek, sebagai berikut: 
1. Cross-ownership selain memiliki dampak langsung terhadap perubahan struktur kepemilikan suatu perusahaan juga akan memberikan dampak perubahan struktur industri dimana perusahaan itu berada. Untuk mengukur apakah cross-ownership yang sedang diteliti memberikan dampak buruk terhadap persaingan, otoritas kompetisi lazimnya memperhatikan perubahan tingkat konsentrasi industri sebelum dan sesudah cross-ownership terjadi. Apabila tingkat struktur industri setelah cross-ownership semakin terkonsentrasi maka hal tersebut memberikan indikasi bahwa crossownership yang dilakukan berdampak buruk terhadap persaingan.

2. Dampak akhir dari cross-ownership yang berdampak buruk terhadap persaingan adalah adanya nilai kerugian konsumen atau disebut consumer loss. Consumer loss muncul sebagai akibat dari tingginya harga jual produk dibandingkan dari yang seharusnya dapat dijangkau lebih murah atau kuantitas output di pasaran yang jumlahnya lebih rendah dari yang seharusnya konsumen dapatkan.

3. Kehadiran price leadership dalam suatu industri menyebabkan pilihan konsumen untuk menikmati harga yang lebih murah menjadi terhambat. Indikasi terjadinya price leadership adalah adanya pola perubahan tarif antar operator yang relatif seragam, tingginya harga produk, serta tingginya margin keuntungan antar pelaku usaha.

Dengan demikian, suatu posisi dominan dianggap sebagai sebuah pelanggaran terhadap undang-undang apabila posisi dominan tersebut secara efektif untuk mendistorsi pasar yang bersangkutan. Jadi, ketentuan Pasal 25 dan Pasal 27 walaupun menurut ketentuan Undang-Undang Nomor 5 Tahun 1999 bersifat per se illegal, namun dalam penerapannya digunakan pendekatan rule of reason. Sebab penggunaan per se illegal akan membatasi pelaku usaha yang efisien dan inovatif serta kompetitif di pasar bersangkutan. ${ }^{21}$

\section{d. Konsistensi Pasal 25 dan Pasal 27 dengan Pasal yang lainnya dalam Undang-undang Nomor 5 Tahun 1999}

Penggunaan sifat larangan rule of reason penerapan pasal 25 dan pasal 27 oleh KPPU, selain mendasarkan kepada teori dasar bahwa menjadi dominan ialah dilarang, kecuali ada penyalahgunaan posisi dominan. alasan lainnya ialah untuk memberikan konsistensi diantara ketentuan Pasal 4, Pasal 13, Pasal 17, Pasal 18 dengan Pasal 25 dan Pasal 27 Undang-Undang Nomor 5 Tahun 1999. Dan berikut ini ketentuan secara lengkapnya: Pasal 4 : Oligopoli

(1) Pelaku usaha dilarang membuat perjanjian dengan pelaku usaha lain untuk secara bersama-sama melakukan penguasaan produksi dan atau pemasaran barang dan atau jasa yang dapat mengakibatkan terjadinya praktek monopoli dan atau persaingan usaha tidak sehat. 
(2) Pelaku usaha patut diduga atau dianggap secara bersama-sama melakukan penguasaan produksi dan atau pemasaran barang dan atau jasa, sebagaimana dimaksud ayat (1), apabila 2 (dua) atau 3 (tiga) pelaku usaha atau kelompok pelaku usaha menguasai lebih dari 75\% (tujuh puluh lima persen) pangsa pasar satu jenis barang atau jasa tertentu.

Pasal 13 : Oligopsoni

(1) Pelaku usaha dilarang membuat perjanjian dengan pelaku usaha lain yang bertujuan untuk secara bersama-sama menguasai pembelian atau penerimaan pasokan agar dapat mengendalikan harga atas barang dan atau jasa dalam pasar bersangkutan, yang dapat mengakibatkan terjadinya praktek monopoli dan atau persaingan usaha tidak sehat.

(2) Pelaku usaha patut diduga atau dianggap secara bersama-sama menguasai pembelian atau penerimaan pasokan sebagaimana dimaksud dalam ayat (1) apabila 2 (dua) atau 3 (tiga) pelaku usaha atau kelompok pelaku usaha menguasai lebih dari 75\% (tujuh puluh lima persen) pangsa pasar satu jenis barang atau jasa tertentu.

Pasal 17: Monopoli

(1) Pelaku usaha dilarang melakukan penguasaan atas produksi dan atau pemasaran barang dan atau jasa yang dapat mengakibatkan terjadinya praktek monopoli dan atau persaingan usaha tidak sehat.
(2) Pelaku usaha patut diduga atau dianggap melakukan penguasaan atas produksi dan atau pemasaran barang dan atau jasa sebagaimana dimaksud dalam ayat (1) apabila:

1. barang dan atau jasa yang bersangkutan belum ada substitusinya; atau

a. mengakibatkan pelaku usaha lain tidak dapat masuk ke dalam persaingan usaha barang dan atau jasa yang sama; atau

b. satu pelaku usaha atau satu kelompok pelaku usaha menguasai lebih dari 50\% (lima puluh persen) pangsa pasar satu jenis barang atau jasa tertentu.

Pasal 18 : Monopsoni

(1) Pelaku usaha dilarang menguasai penerimaan pasokan atau menjadi pembeli tunggal atas barang dan atau jasa dalam pasar bersangkutan yang dapat mengakibatkan terjadinya praktek monopoli dan atau persaingan usaha tidak sehat.

(2) Pelaku usaha patut diduga atau dianggap menguasai penerimaan pasokan atau menjadi pembeli tunggal sebagaimana dimaksud dalam ayat (1) apabila satu pelaku usaha atau satu kelompok pelaku usaha menguasai lebih dari 50\% (lima puluh persen) pangsa pasar satu jenis barang atau jasa tertentu.

Dari ketentuan diatas, maka berikut ini sifat larangan dalam masing-masing pasal seperti yang tergambar dalam tabel 3.

Tabel 3. Sifat Larangan dalam Pasal 4, Pasal 13, Pasal 17, Pasal 18

\begin{tabular}{|c|c|l|c|c|}
\hline \multirow{2}{*}{ No } & \multirow{2}{*}{ Pasal } & \multirow{2}{*}{ Jenis Perbuatan Anti Persaingan } & \multicolumn{2}{|c|}{ Sifat Larangan } \\
\cline { 4 - 5 } & & & Per se illegal & Rule of reason \\
\hline 1. & 4 & Oligopoli & - & $\mathrm{V}$ \\
\hline 2. & 13 & Oligopsoni & - & $\mathrm{V}$ \\
\hline 3. & 17 & Monopoli & - & $\mathrm{V}$ \\
\hline 4. & 18 & Monopsoni & - & $\mathrm{V}$ \\
\hline
\end{tabular}


Menurut ketentuan Pasal 4, Pasal 13, Pasal 17, Pasal 18, bahwa seorang pelaku usaha diduga dapat melakukan praktek monopoli dan/atau persaingan usaha tidak sehat, apabila pelaku usaha atau satu kelompok pelaku usaha menguasai pasar lebih dari 505 dan apabila dua atau tiga pelaku usaha atau satu kelompok pelaku usaha mengusai lebih dari 75\% pangsa pasar. Ketentuan tersbut bersifat rebuttabe, artinya ketentuan tersebut tidak melarang satu pelaku usaha untuk meningkatkan usahanya (pencapaian pangsa pasarnya). Apabila sudah mencapai pangsa pasar lebih dari 50\%, dan apabila dua atau tiga pelaku usaha atau satu kelompok pelaku usaha mengusai lebih dari $75 \%$ pangsa pasar, dengan syarat pencapaian pangsa pasar tersebut diperoleh melalui persaingan usaha yang sehat atau fair. ${ }^{22}$

Sehingga ketika ketentuan pasal 4, Pasal 13, Pasal 17 dan Pasal 18 menggunakan sifat larangan rule of reason maka ketentuan pasal 25 dan pasal 27 juga harus diterapkan dengan menggunakan sifat larangan yang sama, yaitu rule of reason. Jika tidak demikian, maka ketentuan Pasal 25 dan Pasal 27 justru akan bertentangan dengan ketentuan pasal 4, Pasal 13, Pasal 17 dan Pasal 18.

\section{Penerapan Larangan Per Se Illegal dan Rule of Reason dalam Akta Persaingan 2010 Malaysia}

Telah dihuraikan sebelumnya, bahwa untuk melakukan penilaian apakah sebuah perbuatan dianggap anti persaingan, maka terdapat dua konsep pendekatan larangan, yaitu per se illegal (konsep tujuan) dan rule of reason (konsep akibat). Akta Persaingan 2010, rupanya tidak secara tegas menyatakan, sebuah perbuatan anti persaingan ialah menggunakan konsep tujuan ataukah konsep akibat. Oleh itu ialah menjadi kuasa daripada MyCC untuk melakukan analisa dan membuat kesimpulan mengenai hal tersebut.

\section{Perjanjian anti persaingan dalam akta persaingan 2010 Malaysia}

Mengenai sifat larangan ini, dalam garis panduan, ${ }^{23}$ dinyatakan bahwa perjanjian horizontal tertentu dengan "objek" yang terlibat dalam perbuatan kartel adalah “dianggap mempunyai objek ketara menghalang, membatasi atau mengganggu persaingan. Namun dalam Akta Persaingan 2010, tidak ada penjelasan lebih lanjut, sama ada apa yang dimaksud dengan kartel dan juga istilah "objek". Seperti telah diperbincangkan pada bab sebelumnya, bahwa secara umum istilah kartel ialah digunakan untuk menggambarkan, kesepakatan atau kolusif diantara pelaku usaha. Istilah kartel ialah meliputi kartel mengenai penetapan harga, persekongkolan tender, pembatasan produksi dan pembahagian wilayah pasar. ${ }^{24}$

Kartel dianggap sebagai sinonim daripada perjanjian kolusif, yang bertujuan 
saling memberikan keuntungan bagi para

anggota kartel. Oleh itu maka yang dimaksud

istilah objek yang terlibat dalam perbuatan

kartel ialah beberapa wujud perjanjian anti

persaingan sebagaimana diatur dibawah pasal

4 (2) Akta Persaingan 2010, yaitu perjanjian untuk menetapkan harga:;5 market sharing, ${ }^{26}$ perjanjian untuk membatasi atau menetapkan jumlah produksi, saluran keluar pasar atau capaian pasar, pembangunan teknologi; atau investasi; ${ }^{27}$ dan juga perjanjian untuk melakukan persekongkolan tender. ${ }^{28}$

25 Akta Persaingan 2010 melarang pelaku usaha untuk bersepakat menetapkan, sama ada secara langsung atau tidak langsung, harga belian atau harga jualan atau syarat-syarat perniagaan lainnya. Penetapan harga secara langsung, misalnya dilakukan melalui persetujuan untuk menaikkan atau menetapkan harga pada peringkat tertentu, dan penetapan harga tidak langsung, misalnya melalui persetujuan untuk menawarkan atau tidak potongan harga atau istilah-istilah kredit yang sama. Larangan terhadap penetapan harga dalam ketentuan pasal 4 (1) ditujukan kepada semua wujud penetpan harga dalam pasar hiliran atau huluan, sementara(2) hanya terbatas kepada perjanjian penetapan harga horizontal. Di dalam Kasus Nomor MyCC/0003/2012 (ACA), bahwa kesepakatan di antara anggota CHFA untuk menaikkan harga bunga sebesar 10\%, dan kenaikan tersebut mulai berlaku pada 16 Maret 2012 untuk semua bunga yang dijual dipasar Malaysia dan diluar negari kecuali Jepang, adalah sebabkan adanya kenaikan semua biaya produksi seperti gaji pekerja, pupuk, biaya listrik, plastik pembungkus dan lain-lain.

26 Dibawah Akta Persaingan 2010 adalah menjadi kesalahan bagi perusahaan untuk membagi pasar. Perusahaan dapat melakukan kerjasama ini dengan cara:

(1) Membagikan antara mereka pasar, sama ada secara geografi atau jenis pelanggan;

(2) Ini dapat termasuk pesaing bersepakat untuk mengatur pelanggan di antara mereka atau bersepakat untuk masing-masing tinggal dalam wilayah geografi tertentu. Mereka dapat juga bersepakat untuk membeli hanya daripada produsen tertentu juga dapat disifatkan sebagai anti-persaingan. Pesaing bersepakat untuk menjadi ahli dalam produk tertentu, mengenai produk itu sendiri atau dalam teknologi tertentu juga dapat disifatkan sebagai anti-persaingan.

(3) Beroperasi hanya di dalam wilayah yang telah ditentukan untuk mereka.

Tujuan daripada kerjasama ini ialah untuk memastikan tidak ada persaingan untuk barang atau jasa mereka di dalam wilayah tertentu atau untuk jenis pelanggan tertentu saja. Apabila wujud keadaan sebegini, pelanggan akan terhalang daripada mencari tawaran terbaik dan tiada pilihan melainkan membeli dari perushaan yang telah ditentukan di wilayah mereka atau jenis pelanggan.

27 Di bawah Akta Persaingan 2010 adalah menjadi kesalahan bagi perusahaan bersekongkol untuk membataskan atau mengawal produksi, saluran keluar pasar atau capaian pasar, pebangunan teknikal atau teknologi atau pelaburan. Apabila produksi, saluran keluar pasar atau capaian pasar adalah terbatas atau dikawal, penawaran akan berkurang dan harga akan meningkat bahwa penawaran tidak mencukupi untuk memenuhi permintaan. Tambahan pula biaya produksi akan menurun melalui pengurangan perbelanjaan untuk pembangunan teknikal atau teknologi dan pelaburan. Semua langkah ini dilakukan dengan tujuan memanipulasi harga secara tidak jujur dan mendapatkan keuntungan maksimum. Perusahaan yang mengamalkan pelakuan yang tidak sehat ini mendapat keuntungan besar walaupun mereka tidak effisien dan tidak inovatif.

Dengan demikian terdapat tiga jenis pembatasan yang bersifat anti persaingan:

(1) Pembatasan terhadap produksi, sebagai contoh, bersepakat kepada kuota produksi semasa kelembapan ekonomi - ini mempunyai akibat yang sama seperti menetapkan harga yang lebih tinggi;

(2) Pembatasan terhadap wilayah pasar atau akses pasar; ini dapat termasuk pesaing bersepakat di mana warung-warung itu akan ditempatkan, bersepakat untuk membatasi wilayah pasar atau tinggal dalam pasar tertentu sahaja;

(3) Pembatasan terhadap akses kepada pasar oleh peserta baru, yang meliputi :

a. pembangunan teknologi, sebagai contoh, pesaing bersepakat untuk tidak memperkenalkan produk baru atau menetapkan standard teknologi secara kolektif yang menghalang pesaing lain untuk menjual barang yang sama. Contoh lain, ketika pesaing bersepakat untuk tidak membeli teknologi dari produsen tertentu (melakukan pemulauan) dan lain-lain;

b. investasi, sebagai contoh, ialah dengan bersepakat untuk tidak menambah kapasitas produksi.

28 Tipuan bida atau kolusif dalam tender ialah dengan cara mengambil giliran untuk memenangi kontrak bida yang seharusnya berlangsung secara kompetitif adalah contoh penipuan bida. Artinya jika seharusnya perusahaanperusahaan yang sepatutnya bersaing sesam sendiri, maka dengan adalanya tipuan bida, perusahaan-perusahaan ini justeru bersepakat secara rahsia untuk menaikan harga atau merendahkan kualiti barang atau jasa untuk pembeli yang ingin mendapatkan produk atau jasa melalui pembidaan. Di bawah Akta Persaingan 2010, adalah menjadi kesalahan bagi perusahaan terlibat di dalam tipuan bida. 
Selanjutnya, istilah objek diselaraskan dengan tujuan ekonomi, bahwa Akta Persaingan ialah ditujukan "untuk menggalakkan pembangunan ekonomi dengan menggalakkan dan melindungi proses persaingan", oleh karena itu MyCC akan mengambil pendekatan tersebut dalam setiap keputusannya. Dengan demikian, istilah objek merujuk kepada sebuah titik tekan bahwa perjanjian dianggap anti persaingan ketika mempunyai tujuan untuk itu, tanpa mengira lebih lanjut akibat daripada perbuatan itu terhadap persaingan.

Garis Panduan ${ }^{29}$ juga menyatakan, MyCC tidak hanya memeriksa niat biasa sebenar pihak-pihak kepada perjanjian, tetapi juga menilai tujuan yang hendak dicapai oleh perjanjian ini. Jika “objek" suatu perjanjian adalah sangat mungkin mempunyai akibat anti-persaingan yang ketara, maka MyCC dapat mencari perjanjian untuk mempunyai anti-persaingan "objek." Dan Apabila anti-persaingan “objek" dipaparkan, maka MyCC yang tidak perlu meneliti akibat antipersaingan perjanjian. ${ }^{30}$

Pasal 4 (1), menyatakan, suatu perjanjian horizontal atau vertikal antara perusahaan adalah dilarang sepanjang yang perjanjian itu mempunyai tujuan atau akibat menghalangi, membatasi atau mengganggu persaingan secara signifikan dalam apa-apa pasar bagi barang atau jasa. Maka artinya, bahwa kedua-dua perjanjian, sama ada bersifat horizontal (di antara perusahaan di tahap yang sama produksi, yang biasanya bermaksud pesaing dalam pasar yang sama) dan juga vertikal (perjanjian antara pembeli dan penjual di pelbagai peringkat produksi dan rantaian distributor) adalah dilarang jika mereka mempunyai objek anti-persaingan atau akibat yang besar ke atas pasar. dan perjanjian adalah dilarang hanya jika mereka ketara menghalang, membatasi atau memutarbelitkan persaingan dalam apa-apa pasar bagi barang atau jasa di Malaysia.

Istilah "signifikan" artinya ialah perjanjian mestilah mempunyai lebih dari akibat remeh. Perlu diingatkan bahwa akibat akan dinilai sejajar dengan yang dikenal pasti pasar yang berkaitan. Panduan yang baik untuk akibat remeh perjanjian anti-persaingan mungkin bahagian pasar gabungan mereka yang mengambil bahagian dalam apa-apa perjanjian. Sebagai titik permulaan dan memberikan keyakinan yang lebih besar, MyCC dapat menggunakan yang berikut asas dalam menilai sama ada akibat anti-persaingan adalah "penting."

Secara umum, perjanjian anti-persaingan tidak akan dianggap "penting" jika: ${ }^{31}$

1. pihak-pihak kepada perjanjian itu adalah pesaing yang berada di pasar yang sama dan bahagian pasar mereka gabungan pasar yang berkaitan tidak melebihi duapuluh persen $(20 \%)$;

29 Garis Panduan Bab 1 Larangan Perjanjian Anti-Persaingan, hlm. 7.

30 Garis Panduan Bab 1 Larangan Perjanjian Anti-Persaingan, hlm. 7.

31 Garis Panduan Bab 1 Larangan Perjanjian Anti-Persaingan, hlm. 10. 
2. pihak-pihak kepada perjanjian itu tidak pesaing dan semua pihak individu mempunyai kurang daripada 25\% di mana-mana pasar yang berkaitan. Sebagai contoh, perjanjian distributor eksklusif antara distributor dan pengecer tidak daripada mereka mempunyai lebih daripada duapuluh lima persen $(25 \%)$ daripada pasar grosir atau pasar eceran.

Sebuah perjanjian hanya akan dilarang jika mereka mempunyai "tujuan atau akibat ketara menghalangi, membatasi atau mengganggu persaingan. Sedangkan mengenai perjanjian vertikal, secara umumnya, adalah kurang berbahaya kepada persaingan daripada horizontal perjanjian. Perjanjian vertikal biasanya melibatkan satu perusahaan di hulu tahap membekalkan input kepada perusahaan hilir. Walaupun pesaing dalam perjanjian horizontal bersaing antara satu sama lain, perusahaan dalam perjanjian vertikal biasanya mempunyai kepentingan bersama dalam memastikan produk akhir atau jasa adalah kompetitif. Dengan demikian perjanjian yang bersifat vertikal hanya akan dilarang apabila mendatangkan akibat negatis secara signifikan terhadap persaingan.

Seperti penetapan harga horizontal, penetapan harga vertikal mungkin lebih anti persaingan daripada perjanjian vertikal bukan harga. Hambatan vertikal untuk menghadkan harga adalah keupayaan mereka untuk bersaing dengan cara menjual pada harga semula. Hambatan harga secara vertikal dapat menjadi anti persaingan bahwa ianya merampas sebahagian persaingan dalam pasar. Dalam menentukan, baik mengenai perjanjian vertikal ketara menghalangi, membatasi atau mengganggu persaingan, perhatian akan diberikan kepada kuasa pasar perusahaan yang mengenakan hambatan vertikal itu, justifikasi yang dituntut bagi hambatan dan sejauh mana pasar dalam hubungan vertikal dapat dirampas. Juga berkaitan dengan memeriksa akibat anti persaingan berupa hambatan masuk ke dalam pasar yang berkaitan. Satu lagi faktor yang akan dipertimbangkan adalah sama ada terdapat timbal balas kuasa pembeli, yang berarti bahwa pembeli tidak akan ditentukan oleh produsen.

Adalah penting untuk ambil perhatian bahwa Pasal 4 (2) ialah mengatur beberapa jenis tertentu perjanjian horizontal antara perusahaan sebagai tindakan anti-persaingan. Dalam keadaan ini, perjanjian adalah dianggap "mempunyai objek yang menghalangi, membatasi atau mengganggu persaingan dalam apa-apa pasar bagi barang atau jasa”. Ini bermakna bagi perjanjian horizontal, MyCC yang tidak perlu untuk memeriksa apa-apa akibat anti-persaingan perjanjian tersebut, ${ }^{32}$ dengan demikian artinya bahwa pasal 4 (2) ialah menggunakan larangan per se illegal.

Demikian halnya yang dilakukan oleh MyCC dalam kasus penetapan harga oleh para pelaku usaha dalam industri bungabungaan (CHFA), ketika MyCC telah dapat membuktikan bahwa telah terjadi sebuah 
kesepakatan oleh pelaku usaha yang berada dalam sifat hubungan yang horizontal dan perbuatan itu ditujukan untuk membentuk harga, maka tanpa memperhatikan apakah perbuatan itu telah mendatangkan akibat anti persaingan, perbuatan itu ialah dianggap melanggar Akta Persaingan 2010. ${ }^{33}$

Hal yang sama juga dilakukan oleh MyCC dalam kasus pembagian pasar yang dilakukan oleh MAS, AirAsia dan AirAsia X, dengan berdasarkan kepada Garis Panduan Suruhanjaya mengenai Perjanjian AntiPersaingan menyatakan dengan jelas bahwa tidak ada keperluan bagi Suruhanjaya untuk membuktikan "akibat" perjanjian itu sekali satu "objek" perjanjian di bawah pasal 4 (2) terbukti. ${ }^{34}$ Mengenai hal ini mendatangkan keberatan dari pihak MAS dan Air Asia, melalui perwakilannya mereka menyatakan Suruhanjaya tidak menjalankan analisis “objek" yaitu analisis terhadap pasar yang berkaitan, tidak menerima pakai definisi pasar yang sesuai dan tidak menganggap konteks ekonomi yang berkaitan dalam menentukan tujuan yang mungkin atau "objek" yang mendasari kelakuan yang berkenaan. Menurut MAS juga, Suruhanjaya juga tidak menjalankan analisis terhadap apa-apa "akibat" yang timbul akibat perjanjian kerjasama tersebut. MAS juga berhujah bahwa harus ada pemeriksaan atas persaingan sebenar dan potensi yang akan wujud di antara MAS dan AirAsia jika tiada Perjanjian Kerjasama dan juga analisis objektif akibat perjanjian pada persaingan di pasar perlu mempunyai dijalankan. ${ }^{35}$ Namun MyCC tetap dalam pendiriannya, bahwa tidak syak lagi bahwa MAS dan AirAsia adalah pesaing dan Perjanjian Kerjasama tersebut merupakan perjanjian horizontal antara pesaing yang jelas mempunyai tujuan melakukan perkongsian pasar. dengan demikian maka sesuai dengan Akta Persaingan, yang telah menetapkan bahwa apa-apa perjanjian antara pesaing untuk berkongsi pasar menjadi pelanggaran pasal 4 (2) dan oleh itu, ia tidak perlu bagi MyCC untuk menjalankan analisis terhadap akibat.

Sehingga secara keseluruhan, sifat larangan perbuatan anti persaingan di dalam Akta Persaigan 2010, ialah sebagai berikut:

\section{Penyalahgunaan Posisi Dominan dalam Akta Persaingan 2010 Malaysia}

Jenis perbuatan anti persaingan yang lain ialah penyalahgunaan posisi dominan yang diatur dalam pasal 10. Sama dengan UndangUndang Nomor 5 Tahun 1999, Akta Persaingan 2010 juga tidak melarang sebauah perusahaan karena telah mempunyai posisi dominan. Namun Akta Persaingan 2010 melarang

33 MyCC's Decision Against the Cameron Highlands Floriculturist Association, Kes Nombor MyCC/0003/2012(ACA).

34 Garis Panduan Bab 1 Larangan Perjanjian Anti-Persaingan, hlm. 9.

35 MyCC's Decision Against to Malaysian Airline System Berhad, AirAsia Berhad and AirAsia X Sdn. Bhd, Kes Nombor. MyCC.0001.2012., hlm. 23-24. 
Tabel 4: Sifat Larangan Kegiatan Anti Persaingan dalam Akta Persaingan 2010

\begin{tabular}{|c|c|c|c|c|}
\hline \multirow[b]{2}{*}{ No. } & \multirow[b]{2}{*}{ Jenis Kegiatan Anti Persaingan } & \multirow[b]{2}{*}{ Pasal } & \multicolumn{2}{|c|}{ Sifat Larangan } \\
\hline & & & $\begin{array}{l}\text { Per se } \\
\text { illegal }\end{array}$ & $\begin{array}{l}\text { Rule of } \\
\text { reason }\end{array}$ \\
\hline 1. & Perjanjian anti persaingan bersifat vertikal dan horizontal & $4(1)$ & & $v$ \\
\hline 2. & $\begin{array}{l}\text { Perjanjian anti persaingan bersifat horizontal, khususnya } \\
\text { 1) Penetapan harga; } \\
\text { 2) market sharing; } \\
\text { 3) mengatur dan membatasi : } \\
\text { a. jumlah produksi; } \\
\text { b. akses pasar; } \\
\text { c. pembangunan teknologi; atau } \\
\text { d. investasi; atau } \\
\text { 4) persekongkolan tender }\end{array}$ & & $v$ & \\
\hline 3. & Penyalahgunaan posisi dominan & & & $v$ \\
\hline
\end{tabular}

\section{Sumber: Data primer, diolah, 2014}

sebuah perusahaan, baik sendiri ataupun bersama-sama terlibat dalam berbagai macam aktifitas yang berupa penyalahgunaan posisi dominan, oleh karena itulah penyalahgunaan dalam ketentuan pasal 10 ialah bersifat rule of reason.

Penyalahgunaan posisi dominan selalu terjadi dalam industri yang sama, diantara perusahaan yang mempunyai posisi dominan, dengan distributor, pemasok dan pengecer. Beberapa bentuk penyalahgunaan posisi dominan menurut pasal $10:{ }^{36}$

1. Diskriminasi harga

Perbedaan harga mungkin saja terjadi ketika lokasi pasar untuk barang sejenis telah menyebabkan cost pengangkutan yang lebih tinggi, atau harga menjadi berbeda dalam pembelian secara grosir dengan eceran. Dalam hal-hal yang demikian, maka perbedaan harga bukan menjadi sebuah kesalahan dibawah Akta Persaingan 2010. Namun apabila terdapat sebuah perusahaan yang pada awalnya telah mempunyai posisi dominan dan kemudian menyalahgunakannya dengan menerapkan harga yang berbeda bukan disebabkan faktor ekonomi, maka disitulah terjadi persaingan usaha yang tidak adil.

\section{Predatory pricing}

Ketika perusahaan berperilaku sebagai predator, hendak memangsa perusahaan pesaingnya dengan menetapkan harga dibawah cost untuk menghilangkan persaingan. Dalam predatory pricing, sebuah perusahaan menjual barang dibawah cost dengan tujuan untuk menghilanhkan pesaingnya dari pasar dan kemudian tampil sebagai pemonopoli pasar dan menaikkan harga untuk mendapatkan keuntungan setinggitingginya. Pada awalnya konsumen menikmati harga yang rendah ini, namun pada akhirnya ketika tidak ada lagi 
pilihan, sebab perusahaan pesaing telah tersingkir, maka konsumen akan terpaksa memyara harga yang sangat mahal, karena tidak ada pilihan.

3. Pemboikotan

Dengan posisi dominan yang dimilikinya, sebuah perusahaan bisa menggunakan kesempatan untuk menolak memasok sebuah barang hasil produksinya kepada perusahaan pesaingnya, atau hanya mau memasok kepada perusahaan tertentu saja. Hal ini dilakukan untuk memperkuat hubungan perdagangan diantara para pihak yang terlibat pemboikotan dan untuk seterusnya menguasai pasar.

4. Tying Agreement

Ketika sebuah perusahaan penghasil produk pengikat yang mempunyai posisi dominan, memaksa konsumen untuk turut membeli poduk kedua (produk terikat), sementara di dalam pasar tidak terdapat pelaku usaha lain yang memproduksi barang sejenis.

5. Perjanjian Tertutup

Ialah membeli barang atau sebuah sumber daya yang terbatas yang sesungguhnya lebih diperlukan oleh pelaku usaha pesaing, namun demi alasan menghalangi produksi pelaku usaha pesaingnya itu, pelaku usaha yang mempunyai posisi dominan tersebut tetap 'mengalah untuk membeli' meskipun tidak membutuhkannya secara langsung. Jadi inti daripada penyalahgunaan posisi dominan ini ialah, semua perbuatan yang sengaja dilakukan untuk memaksa pelaku usaha pesaingnya keluar dari pasar. Sehingga perusahaan yang domina tersebut terus dapat menguasai pasar dengan beberapa penjual atau penyalur tertentu. Dalam kondisi yang demikian, maka perusahaan yang dominan tersebut akan bebas menetapkan harga serta prasayaratdistribusi dan penjualan yang bersifat anti persaingan.

\section{Simpulan}

Baik Undang-Undang Nomor 5 Tahun 1999 dan juga Akta Persaingan 2010 Malaysia, menerapkan sifat larangan per se illegal ataukah rule of reason. Penerapan sifat larangan tersebut selain melalui sebuah penilaian bagaimana tingkatan akibat sebuah perbuatan anti persaingan mampu mendistorsi pasar dan menghalangi hingga menghilangkan persaingan sama sekali. Perlu dipertimbangkan pula adanya keselarasan antara peraturan normatif dalam Undang-Undang dengan teori dasar persaingan itu sendiri. Dengan demikian kepastian hukum dalam penegakan hukum persaingan dapat terus ditegakkan. 


\section{DAFTAR PUSTAKA}

Buku

A.M. Tri Anggraini, 2003, Larangan Praktek Monopoli dan Persaingan Usaha Tidak Sehat, Perpustakaan Nasional, Jakarta

Andi Fahmy Lubis, et all, 2009, Persaingan Usaha antara Teks dan Konteks, Published and Printed with Support of Deutsche Gesellschaft für Technische Zusammenarbeit (GTZ) GmbH, Jakarta.

Asril Sitompul, 1999, Praktek Monopoli dan Persaingan Usaha Tidak Sehat (Tinjauan terhadap Undang-Undang No. 5 Tahun 1999), Citra Aditya, Bandung.

Elyta Ras Ginting, 2001, Hukum Anti Monopoli Indonesia, Analisis dan Perbandingan UU No. 5 Tahun 1999, Citra Aditya Bakti, Bandung.

Herbert Hovenkamp, 1993, Antiturst, St.

Paul Minnesota, West Publishing.

Henry R. Cheeseman, 2001, Business

Law - Ethical, International \&

E-Commerce Enviroment, Fourth

Edition, Upper Saddle River, New Jersey.

Johnny Ibrahim, 2006, Hukum Persaingan

Usaha: Filosofi, Teori dan Implikasi

Penerapannya di Indonesia,

Bayumedia Publishing, Malang.

Lawrence Anthony Sullivan, 1997, Antitrust,

West Publishing, Co, St. Paul Minnesota.
L. Budi Kagramanto, 2008, Larangan Persekongkolan Tender (Prespektif Hukum Persaingan Usaha), Srikandi. Munir Fuady, 1998, Hukum Anti Monopoli

Menyongsong Era Persaingan Sehat, Citra Aditya Bakti, Jakarta.

Ningrum Sirait, 2004, Hukum Persaingan

Usaha di Indonesia, Pustaka Bangsa Press, Medan.

Rahmadi Usman, 2012, Hukum Persaingan Usaha di Indonesia dalam Teori dan Praktik serta Penerapannya di Indonesia, Sinar Grafika, Jakarta.

R. Sheyam Khemani and D. M. Shapiro, 1996, Glossary af Industrial Organisation Economics and Competition Law, OECD, Paris.

Susanti Adi Nugroho, 2001, Undang-undang Persaingan Usaha di Indonesia, Puslitbang/Diklat Mahkamah Agung.

Susanti Adi, 2012, Hukum Persaingan Usaha di Indonesia dalam Teori, Praktik dan Penerapannya, Kencana Prenada Media Grup, Jakarta.

Stephen F. Ross, 1993, Principles of Antitrust Law, The Foundation Press, Inc., Westbury New York.

Thomas E. Sullivan and Jeffrey L. Harrison, 1994, Understanding Antitrust and Its Economics Implications, Matthew Bender \& Co., New York. 


\section{Jurnal}

Robert H. Bork, The Rule of Reason and The Per se Concept: Price Fixing and Market Division, The Yale Law Journal, Volume 74, Januari 1996.

Syamsul Maarif, Tantangan Penegakan Undang-undang Persaingan di Indonesia, Jurnal Undang-undang Bisnis Volume 19, Mei - Juni 2002. Yakub Adi Krisanto, Tarif SMS. Penetapan Harga dan Perlindungan Pengguna di Pasaran Telekomunikasi Seluler

di Indonesia, Jurnal Hukum Bisnis. Volume 28 No. 2, 2009.

Peter Nealis, Per se Legality; a new Standart in Antitrust Adjudication Under the Rule of Reason, Ohio St. Law Journal, Volume 61 No. 347, 2000.

\section{Makalah}

Ahmad Junaidi, 2013, Asas Comity dan Hukum Persaingan di ASEAN, Media Berkala Komisi Pengawas Persaingan Usaha, Edisi 42.

J. David Reizel, et.al. 2001, Contemporary Business Law, McGraw-Hill Publishing Company, Fourth Edition.

Sukarmi, 2007, Persaingan Sehat dalam Pelaksanaan Pengadaan Barangan/ Perkhidmatan, Kertas kerja dalam Semiloka "Optimalisasi Pengadaan Barangan dan Perkhidmatan di RS" di Hotel Aston Atrium Senen, Jakarta.

Syamsul Maarif dan B.C. Rikrik Rizkiyana, Posisi Undang-undang Persaingan
Usaha dalam Sistem Undang-undang Nasional, disampaikan sebagai bahan bacaan seminar sehari "Refleksi Lima Tahun UU No. 5/1999”, Jakarta / Surabaya, Maret 2004.

James E. Hartley, 1999, The Rule of Reason, American Bar Association (ABA), Monograph No. 23.

\section{Artikel}

KPPU, Frequently Asked Question (FAQ), www. kppu.go.id.

http://warkahdaily.blogspot.com/2010/07/ a k t a - pers a ing a n - 2010 dikuatkuasa-2012.html,

Akta

Persaingan 2010 Dikuatkuasa 2012 Wujud Persaingan Sihat Dalam Industry, Kuala Lumpur, 5 Juli 2010, http://bisnis.news.viva.co.id/ news/read/174056-dagang-indonesiamalaysia--siapa-untung-.

Thomas Misslin, Recent Developments in the Rule of Reason dan Per Se Standars in American Antitrst Law.

Yakub Adi Krisanto, Prinsip Rule of reason dan Per se rule dalam Undangundang Persaingan Indonesia, http://yakubadikrisanto.wordpress. com/2008/06/03/prinsip-rule-ofreason-dan-per-se-illegal/.

Menteri Perdagangan Dalam Negeri, Koperasi dan Kepenggunaan Datuk Seri Ismail Sabri Yaakob, http://warkahdaily. blogspot.com/2010/07/aktapersaingan-2010-dikuatkuasa-2012. 
html, Akta Persaingan 2010 Dikuatkuasa 2012 Wujud Persaingan Sihat Dalam Industry, Kuala Lumpur, 5 Juli 2010.

\section{Peraturan Perundang-undangan}

Akta Persaingan 2010 Malaysia.

Undang-undang Nomor 5 Tahun 1999 tentang

Larangan Monopoli dan Persaingan Usaha Tidak Sehat.

Sherman Act 1890.

Garis Panduan Bab 1 Larangan Perjanjian Anti-Persaingan.

\section{Putusan dan Kasus}

Putusan Nomor 01/KPPU-L/2003, mengenai Integrasi Vertikal oleh PT Garuda Indonesia.

Putusan KPPU Nomor 09/KPPU-L/2009 Mengenai Praktek Monopoli dan/atau Persaingan Usaha Tidak Sehat atas Akuisisi PT Alfa Retailindo.

Putusan Perkara Nomor 07/KPPU-L/2007, KPPU melakukan analisa terhadap dampak dari Cross-ownership yang dilakukan Kelompok Temasek.

United States vs. Trans-Missouri Freight Association, 166 U.S. 290, 17 S. Ct. 540, 41 L. Ed., 1007 (1897).
United States vs. Trans-Missouri Freight Association, 171 U.S. 505, 19 S. Ct. 25, 43 L. Ed., 259 (1898).

Standart Oil Co. of N.J. vs United States, 221 U.S. 1,31 S. Ct. 502, \%\% L. Ed. 619 (1911).

Chicago Board of Trade vs. United States, 246 U.S. 231 (1918).

Standard Oil, Co. v. United States, 221 U.S. 1, 31 S.Ct. 502, 55 L. Ed. 619 (1911).

Topco v United States, 405 U.S.

Kasus National Society of Professional Engineers v. United States, 435 U.S.

MyCC's Decision Against to Malaysian Airline System Berhad, AirAsia Berhad and AirAsia X Sdn. Bhd, Kes Nombor. MyCC.0001.2012.

MyCC's Decision Against to Malaysian Airline System Berhad, AirAsia Berhad and AirAsia X Sdn. Bhd, Putusan Nomor. MyCC.0001.2012.

\section{Kamus}

Bryan A. Graner, 2004, Black's Law Dictionary, Eighth Edition. 